INTERNATIONAL JOURNAL OF MULTIDISCIPLINARY RESEARCH AND ANALYSis

ISSN(print): 2643-9840, ISSN(online): 2643-9875

Volume 04 Issue 11 November 2021

DOI: 10.47191/ijmra/v4-i11-33, Impact Factor: 6.072

Page No.- 1691-1694

\title{
Purification of Waste Water of Oil-And-Fat Production By Compositions of Reagent-Adsorbents
}

\author{
Dilnoza Saidakbarovna Salihanova ${ }^{1}$, Izzat Dusimbatovich Eshmetov ${ }^{2}$, Feruza Nabievna Agzamova ${ }^{3}$, \\ Durdona Abdulloyevna Azimova ${ }^{4}$, Muxtasar Abdumutallib kizi Ismoilova ${ }^{5}$ \\ 1,2Doctor of technical sciences, professor, Institute of general and inorganic chemistry of Academy of Sciences of the Republic of \\ Uzbekistan \\ ${ }^{3}$ Junior researcher, Institute of general and inorganic Chemistry of Academy of Sciences of the Republic of Uzbekistan \\ ${ }^{4}$ Researcher, Institute of general and inorganic chemistry of Academy of Sciences of the Republic of Uzbekistan \\ ${ }^{5} \mathrm{PhD}$ student, Namangan Institute of Engineering and Technology
}

\begin{abstract}
This article shows the possibility of using reagent-adsorbent compositions, i.e. charred defecate obtained at $600{ }^{\circ} \mathrm{C}$ and activated bentonite of the Askamar deposit in a ratio of 1:5.

It was found that with the use of reagent-adsorbent compositions it will allow to purify wastewater from oil and fat production to $\mathrm{pH}-7.2$ and transparency of 0.44 , and also the water hardness is reduced from $17 \mathrm{mEq} / \mathrm{I}$ to $4.0 \mathrm{mEq} / \mathrm{I}$, which allow the recycling of wastewater for technical needs.
\end{abstract}

KEYWORDS: purification, waste water, activation, defecate, oil, bentonite, composition, MPC, pH, transparency, hardness.

\section{INTRODUCTION}

The fat and oil industry produces various types of products for national production, where a large amount of wastewater is generated, which greatly pollutes the environment. Typically, wastewater from fat and oil enterprises is gray and contains a sufficient amount of suspended solids, sediments and turbidity, which is a fertile basis for rapid decomposition, accompanied by a characteristic putrefactive odor. Such effluents need to be purified in stages up to MPC standards in order to create the possibility of re-use as industrial waters.

When designing treatment facilities for such wastewater, it is important to take into account that mixtures with and without fatty impurities in their composition must be treated separately. The active reaction of the medium is $\mathrm{pH} 6.7$, the content of fat is $256-396 \mathrm{mg} / \mathrm{l}$. Fat is most often present in the form of vegetable oils, small amounts of which cover the water mirror, making it difficult for oxygen to re-aerate and dissolve. Passing through the sewer networks, these oils adhere to the channel walls, glue contaminants, which reduces the flow cross section. In addition, organic acids and nitrogen-containing substances are present in wastewater.

The presence of a large amount of organic compounds in the effluent, which quickly decompose, causes acidic fermentation, resulting in rotting. Wastewater from enterprises is discharged into various sewerage networks, depending on the characteristics of the effluent [1-5].

\section{THE MAIN FINDINGS AND RESULTS}

In most Western European countries, flotation with incineration of production wastes is used, in the USA, Germany, Italy - chemical reagent methods. In Italy, in the field of fat processing technology, a two-stage wastewater treatment is proposed: fat removal by flotation and neutralization to obtain the optimal pH for the life of microorganisms, and then biological treatment using active sludge. The biological sludge obtained in this way is used as fertilizer in agricultural fields [6-9].

For this purpose, the composition of waste water from fat and oil enterprises has been studied. The results are shown in table 1.

As the results of analyzes show, the anionic and cationic composition of wastewater is much higher than the MPC norm. Particularly high values for suspended solids and water hardness. 
Purification of Waste Water of Oil-And-Fat Production By Compositions of Reagent-Adsorbents

Table 1. Composition of waste water from fat and oil production

\begin{tabular}{|c|c|c|c|c|}
\hline \multirow[t]{2}{*}{ Cations } & \multicolumn{2}{|c|}{ Content per liter } & \multirow{2}{*}{\multicolumn{2}{|c|}{ Other indicators }} \\
\hline & $\mathrm{mg} / \mathrm{I}$ & $\%$ - eq / I & & \\
\hline $\mathrm{Na}^{+}$ & 211 & 80 & Hardness mEq / I: total & 17,50 \\
\hline $\mathrm{K}^{+}$ & 44 & 1 & Carbonate & 17,50 \\
\hline $\mathrm{NH}_{4}^{+}$ & 1,0 & & Non-carbonate & - \\
\hline $\mathrm{Ca}^{2+}$ & 900 & 35 & $\mathrm{pH}$ & 3,90 \\
\hline $\mathrm{Mg}^{2+}$ & 882 & 57 & $\mathrm{CO}_{2}$ free $\mathrm{mg} / \mathrm{I}$ & G.m \\
\hline $\mathrm{Fe}^{3+}$ & $<0,3$ & & $\mathrm{CO}_{2}$ agr mg / I & \\
\hline $\mathrm{Fe}^{2+}$ & 1,2 & & $\mathrm{SiO}_{2} \mathrm{mg} / \mathrm{I}$ & \\
\hline Total & & 100 & & Dry residue: $\mathrm{mg} / \mathrm{I}$ \\
\hline \multirow{2}{*}{\multicolumn{3}{|c|}{ Anions }} & Experimental & $9460 \mathrm{mg} / \mathrm{I}$ \\
\hline & & & Calculated & $8020 \mathrm{mg} / \mathrm{I}$ \\
\hline $\mathrm{Cl}^{-}$ & 532 & 12 & \multicolumn{2}{|r|}{ Physical properties } \\
\hline $\mathrm{SO}_{4}^{2-}$ & 5448 & 88 & Transparency & Transparent after filtration \\
\hline $\mathrm{NO}_{2}^{-}$ & $<0,01$ & & Taste & Strongly salty \\
\hline $\mathrm{NO}_{3}^{-}$ & $<1$ & & Color & No color \\
\hline $\mathrm{CO}_{3}^{-}$ & - & & Smell & Without smell \\
\hline $\mathrm{HCO}_{2}^{-}$ & - & & Sediment & A precipitate forms on standing \\
\hline Total & & 100 & Suspended substances, mg / I & 209 \\
\hline
\end{tabular}

For wastewater treatment, a previously developed $[10,11]$ adsorbent reagent, carbonized defecate waste from sugar production and activated bentonite were used (activation was carried out with 10\% sulfuric acid for 1 hour with gentle stirring, then neutralized to $\mathrm{pH} 7$ and dried in drying cabinet $100-105^{\circ} \mathrm{C}$ to constant weight) of the Askamar deposit and their compositions. In this case, the amount of adsorbent was $5 \%$ of the total mass of water. The $\mathrm{pH}$ of the water was 3.5 , and the transparency was 220. The results obtained are shown in table. 2 .

Table 2. Wastewater treatment by the proposed adsorbent reagent and their compositions

\begin{tabular}{|c|c|c|}
\hline Adsorbent type & $\mathrm{pH}$ & Water transparency \\
\hline $\begin{array}{l}\text { Carbonized defecate and activated bentonite of the Askamar deposit in a ratio of 1: } \\
\qquad 9 .(\mathrm{K}-1)\end{array}$ & 9,10 & \\
\hline $\begin{array}{l}\text { Carbonized defecate and activated bentonite of the Askamar deposit in a ratio of 1: } \\
\qquad 7 .(\mathrm{K}-2)\end{array}$ & 8,12 & \\
\hline $\begin{array}{l}\text { Carbonized defecate and activated bentonite of the Askamar deposit in a ratio of 1: } \\
\qquad 5 .(\mathrm{K}-3)\end{array}$ & 7,2 & \\
\hline Activated bentonite of the Askamar deposit. (control) & 39 & 5,8 \\
\hline Carbonized defect (control) & 9,2 & \\
\hline
\end{tabular}




\section{Purification of Waste Water of Oil-And-Fat Production By Compositions of Reagent-Adsorbents}

As can be seen from table 2. with a decrease in the amount of activated bentonite of the Askamar deposit, the $\mathrm{pH}$ of the water and the transparency decrease to the MPC norms. This is especially noticeable when using the composition $\mathrm{K}-3$, where the charred defecate and activated bentonite of the Askamar deposit in a ratio of $1: 5$ the $\mathrm{pH}$ is 7.2 and the transparency is 0.44 .

Further, the effect of the compositions on the composition was studied after purification and chemical analysis was carried out. (Table 3.)

As can be seen from Table 3. with the use of the proposed compositions of the reagent-adsorbent $\mathrm{K}-3$, the indicators were much improved than the initial ones (Table 1). This once again confirms the correctness of the selection of the compositions of the adsorbent reagent in the amount of $5 \%$ of the total amount of wastewater.

Table 3. Composition of wastewater from oil and fat production after purification by the proposed compositions of reagentadsorbents

\begin{tabular}{|c|c|c|c|c|}
\hline \multirow{2}{*}{ Cations } & \multicolumn{2}{|c|}{ Content per liter } & \multicolumn{2}{|r|}{ Other indicators } \\
\hline & $\mathrm{mg} / \mathrm{l}$ & $\%-$ eq / I & & \\
\hline $\mathrm{Na}^{+}$ & 211 & 80 & Hardness mEq / I: total & 4,00 \\
\hline $\mathrm{K}^{+}$ & 7 & 1 & Carbonate & 4.00 \\
\hline $\mathrm{NH}_{4}^{+}$ & 1,5 & 1 & Non-carbonate & - \\
\hline $\mathrm{Ca}^{2+}$ & 20 & 9 & $\mathrm{pH}$ & 6,60 \\
\hline $\mathrm{Mg}^{2+}$ & 12 & 9 & $\mathrm{CO}_{2}$ free $\mathrm{mg} / \mathrm{I}$ & G.m \\
\hline $\mathrm{Fe}^{3+}$ & $<0,3$ & & $\mathrm{CO}_{2}$ agr $\mathrm{mg} / \mathrm{I}$ & \\
\hline $\mathrm{Fe}^{2+}$ & $<0,3$ & & $\mathrm{SiO}_{2} \mathrm{mg} / \mathrm{I}$ & \\
\hline Total & & 100 & & Dry residue: $\mathrm{mg} / \mathrm{I}$ \\
\hline \multirow{2}{*}{\multicolumn{3}{|c|}{ Anions }} & Experimental & $1929 \mathrm{mr} / л$ \\
\hline & & & Calculated & $702 \mathrm{Mr} / л$ \\
\hline $\mathrm{Cl}^{-}$ & 28 & 7 & \multicolumn{2}{|r|}{ Physical properties } \\
\hline $\mathrm{SO}_{4}^{2-}$ & 67 & 12 & Transparency & Transparent after filtration \\
\hline $\mathrm{NO}_{2}^{-}$ & $<0,01$ & - & Taste & Strongly salty \\
\hline $\mathrm{NO}_{3}^{-}$ & 145 & 20 & Color & No color \\
\hline $\mathrm{CO}_{3}^{-}$ & No & - & Smell & Without smell \\
\hline $\mathrm{HCO}_{2}^{-}$ & 421 & 61 & Sediment & A precipitate forms onstanding \\
\hline Total & & 100 & Suspended substances, $\mathrm{mg} / \mathrm{I}$ & 205 \\
\hline
\end{tabular}

Next, microbiological analyzes of the initial and treated wastewater were carried out with the proposed compositions. Determination of the total microbial number was carried out by inoculating an aqueous sample on a solid nutrient medium (meatpeptone agar) [12]. 


\section{Purification of Waste Water of Oil-And-Fat Production By Compositions of Reagent-Adsorbents}

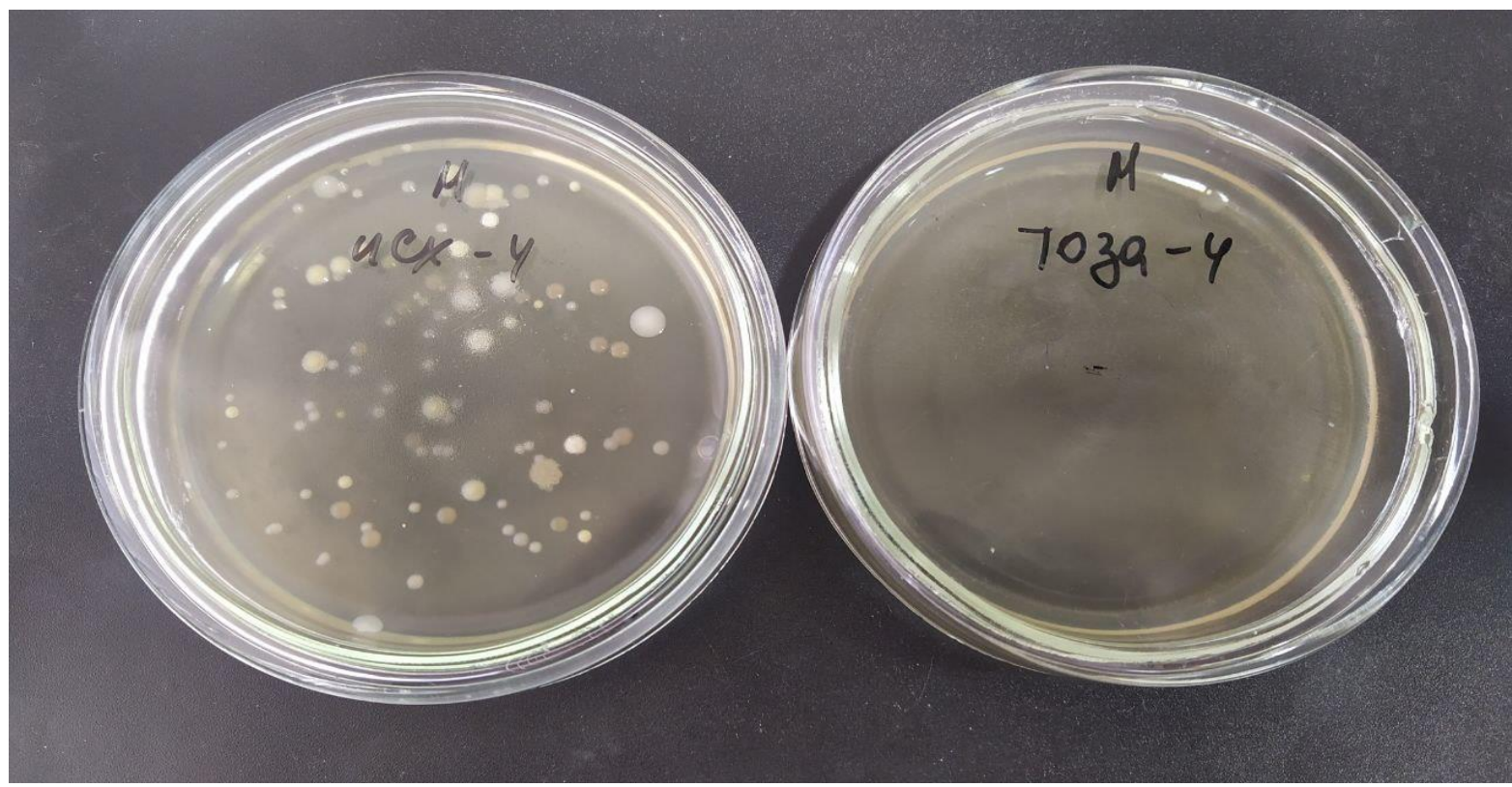

Fig. Drawings before and after cleaning with the proposed adsorbent reagents

As can be seen from the figure, bacteria multiplied in the initial wastewater samples after microbiological tests, however, bacteriological appearance was practically not detected in the purified sample.

\section{CONCLUSION}

Thus, the use of charred defecate and activated Askamarsky bentonite in a ratio of 1: 5 will allow to purify wastewater from oil and fat production to $\mathrm{pH}-7.2$ and transparency of 0.44 , and the water hardness is also reduced from $17 \mathrm{mg}$-eq / I to $4.0 \mathrm{mg}$-eq / I. This will allow the recycling of wastewater for technical needs.

\section{REFERENCES}

1) Ecology and Economics of Natural Resource Use / Edited by E.V. Girusova - M.: UNITY-DANA, 2007.

2) Blagadyreva, A.M. Evaluation of the effectiveness of the use of thermally modified defecate for the purification of wastewater from oil products and explanation of the mechanism of the water purification process // Ecology, energy and resource conservation, environmental protection and human health, waste disposal: abstracts. report International Scientific and Practical Conference, 2009 Kharkov, Vol.2. S. 333 -334.

3) Sverguzova Zh.A. Wastewater treatment with modified defect / Zh.A. Sverguzova // Ecology of human health. Protection of air and water basins. Waste utilization: collection of scientific articles of the International Scientific and Practical Conference / Shelkino (Ukraine), June 4-8, 2007, Kharkiv: Ryder. Vol. 1. -WITH. 219-220.

4) Usmanov RM, Eshmetov I., Salikhanova D., Agzamova F., Eshmetov R., Sharipov A. Physical-Chemical Properties of Thermoactivated Defecate for Purification of Acid Waste Waters // International Journal of Innovative Technology and Exploring Engineering (IJITEE) ISSN: 2278-3075, Volume-9 Issue-2, December 2019.P. 1184-1186.

5) Berezutsky V. V. To the question of the possibility of utilization of fat-containing wastewater generated at the enterprises of the oil and fat industry / V. V. Berezutsky, V. V. Gorbenko, I. A. Mezentseva // Eastern-European Journal of Advanced Technologies = Eastern - European journal of enterprise technologies. - 2011. - No. 6/8 (54). - S. 57-60.

6) Nadysev V.S. Wastewater treatment in the oil and fat industry. - M .: Food industry, 1976.

7) Yaromsky V.N. Wastewater treatment for food and processing enterprises. Minsk: Ed. Center BSU, 2009.171 p.

8) Kuznetsova LS, Snezhko AG, Borisova ZS et al. Purification and disinfection of waste water from processing enterprises of the agro-industrial complex // Food industry. 2002. No. 10. S. 52-53.

9) Bazaryan M.M., Berezutsky V.V. Purification of fat-containing effluents in column electric coagulators. Oil and fat industry, 1984, No. 8 pp. 29-31.

10) Salikhanova D.S., Azimova D.A., Eshmetov I.D., Umirov F.E. .41-47

11) I.D. Eshmetov, R.M. Usmonov, D.S., Salikhanova, F.N. Agzamova, S.R. Shamuratova. Neutralization of acidic effluents of fat and oil enterprises with modified defect // "Composite materials" Tashkent. 2019. No. 2. S. 109-111.

12) Methodology "SanPiN 2.1.4.1175-02 Hygienic requirements for water quality in decentralized water supply. Sanitary protection of sources. "," Determination of the total microbial number. 